Wright State University

CORE Scholar

Earth and Environmental Sciences Faculty

Publications

Earth and Environmental Sciences

9-2019

\title{
Increasing Expression of Civic-Engagement Values by Students in a Service-Learning Chemistry Course
}

\author{
Audrey McGowin \\ Wright State University - Main Campus, audrey.mcgowin@wright.edu \\ Rebecca Teed \\ Wright State University - Main Campus, rebecca.teed@wright.edu
}

Follow this and additional works at: https://corescholar.libraries.wright.edu/ees

Part of the Earth Sciences Commons, and the Environmental Sciences Commons

\section{Repository Citation}

McGowin, A., \& Teed, R. (2019). Increasing Expression of Civic-Engagement Values by Students in a Service-Learning Chemistry Course. Journal of Chemical Education, 96 (10), 2158-2166.

https://corescholar.libraries.wright.edu/ees/139

This Article is brought to you for free and open access by the Earth and Environmental Sciences at CORE Scholar. It has been accepted for inclusion in Earth and Environmental Sciences Faculty Publications by an authorized administrator of CORE Scholar. For more information, please contact library-corescholar@wright.edu. 


\title{
Increasing Expression of Civic-Engagement Values by Students in a Service-Learning Chemistry Course
}

\author{
Audrey E. McGowin* \\ Department of Chemistry, Wright State University, Dayton, Ohio 45435, United States \\ Rebecca Teed \\ Department of Earth and Environmental Sciences, Wright State University, Dayton, Ohio 45435, \\ United States
}

\begin{abstract}
A service-learning course at a mid-sized Midwestern research university was modified over a period of six years to integrate best-practice pedagogies that have been shown to increase civic engagement by students. Best-practice pedagogies included regular interaction with community partner(s), significant time spent on the service activity, and regular reflection (written and verbal) on the implications of the service activity. Besides water quality monitoring, students performed private well water analysis, wrote multiple formal reflection papers, and presented a public talk on the results of their project that included significant discussion time with community partners. Authentic expression of civic engagement values was assessed in final written reflections submitted by students to determine the effect new pedagogies had on students' civic and professional identities. Five values were assessed; (1) identity within the community, (2) commitment to civic engagement, (3) connection between academic content and service, (4) teamwork, and (5) communication with community partners. Statistical analysis showed that the differences in expression of civic-engagement values between pre- and postconditions of applying service-learning best practices were significant. The most effective strategy employed multiple written reflections where students were provided with specific reflection prompts and a grading rubric, a public presentation by students of the results, significant interaction between students and individual partners, in-class discussion of teamwork, and in-class discussion of scientists as citizens.
\end{abstract}

This document is the Accepted Manuscript version of a Published Work that appeared in final form in the Journal of Chemical Education, copyright (c) American Chemical Society after peer review and technical editing by the publisher. To access the final edited and published work see https://pubs.acs.org/doi/10.1021/acs.jchemed.9b00221 

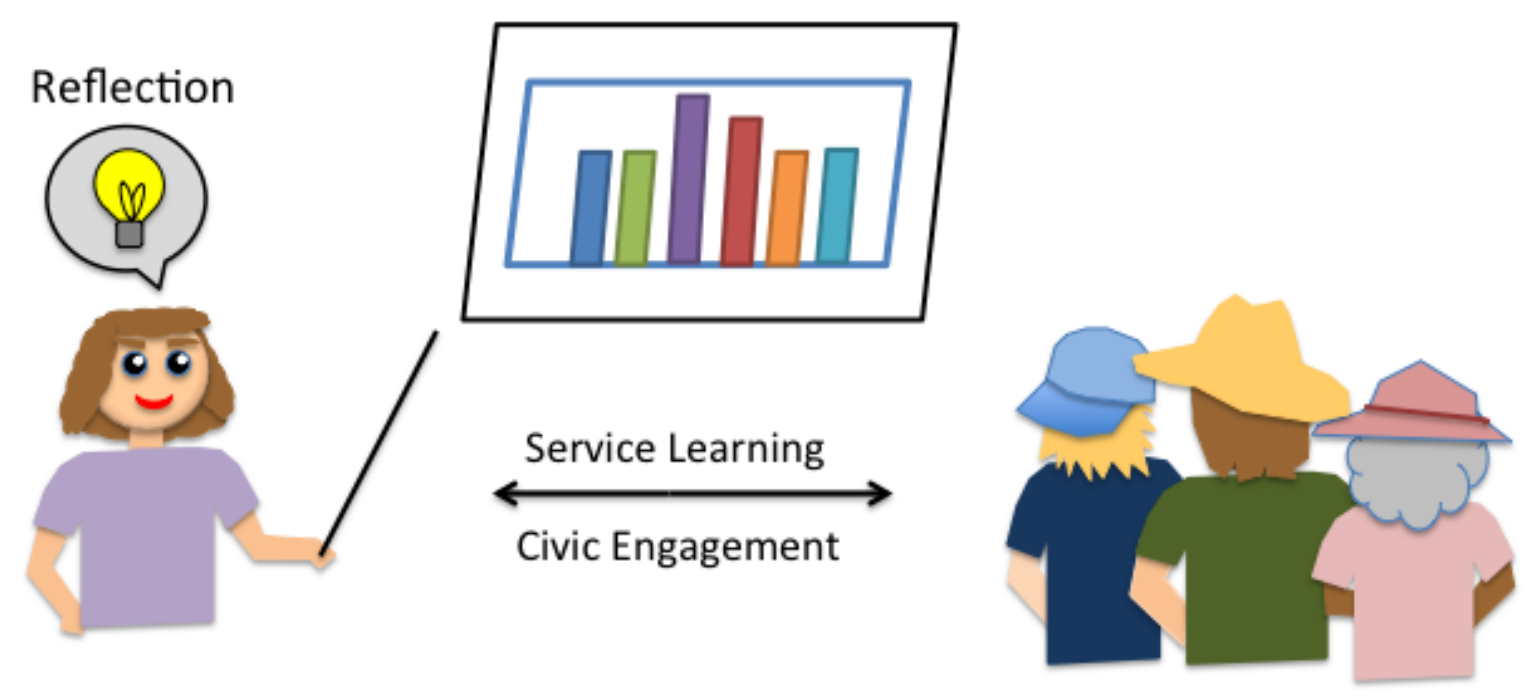

\section{KEYWORDS}

Upper-Division Undergraduate, Curriculum, Environmental Chemistry, Communication/Writing, Testing/Assessment, Learning Theories, Student-Centered Learning, Professional Development

\section{INTRODUCTION}

Science, technology, engineering, and mathematics (STEM) students at research universities have few opportunities to participate in civic engagement activities and are much less likely to reflect on issues important to their community as part of their coursework. ${ }^{1,2}$ Service learning is a collaborative and experiential form of civic engagement that draws on content knowledge gained by students that is applied to a demonstrated need within the community. ${ }^{3-6}$ The experience must promote mastery of course content and requires that students collaborate with community partners to solve a problem or investigate an issue. Students must also reflect on their service-learning experience, an activity that has been demonstrated to increase learning of course content as well as increased self-discovery and civic engagement. ${ }^{7-11}$ Therefore, the point is not to perform charitable acts, but to broaden one's understanding of how one's profession fits into society, to learn that professionals do not exist in a rarified atmosphere but are beholden to the society in which they practice..$^{3,4}$

The best pedagogies for increasing civic engagement and academic development in all disciplines include having students participate in a service-learning project in which students (a) regularly 
interact with community partner(s), (b) spend a significant amount of time ( $>15 \mathrm{~h}$ ) on the service activity, and (c) reflect regularly on their experiences in discussions with all participants and in written reflection papers. ${ }^{12}$ Additionally, the American Chemical Society (ACS) Committee on Professional Training (CPT) has stated that chemistry students must develop communication skills, master problem-solving, and be able to function effectively as part of a team. ${ }^{13}$ Working as part of a problemsolving team that is engaged with their community is an ideal way to help students develop these critical professional skills.

\section{Reflection}

Formal reflection is an essential part of service learning that is often overlooked or not fully actualized when service-learning programs are designed for chemistry students. ${ }^{13}$ Deep reflection imparts context and meaning to an experience. ${ }^{4,5,14}$ When done effectively, reflection leads the student from remembering facts to critical thinking and to increasing self-awareness and understanding of societal issues. ${ }^{14,15}$ Effective reflection promotes transcendence from a student mindset to that of a more confident professional. $5,16,17$

Reflection can take various forms such as speaking, writing, creating media presentations, and having group discussions. ${ }^{8,9,10}$ Oral presentations help students practice speaking skills and increase self-confidence. Whatever form reflection takes, it must be adequately structured so students can make the connection between course content, service, and community issues. Products of reflection are the evidence that students have learned something complex and relevant. 5,8

Stimulating deep reflection by students regarding societal issues can be a challenge ${ }^{7}$, particularly in chemistry since chemists are formed in a culture of reporting only facts in a laboratory report in passive voice. Discipline-specific strategies to aid instructors in stimulating and evaluating student reflection are lacking. ${ }^{3,4}$ In chemistry, student surveys and questionnaires are often employed as reflection tools, before and/or after service-learning activities, ${ }^{13,18-22}$ but these are more measures of student opinion than of learning or personal growth. ${ }^{8}$ Surveys cannot provide context and meaning. To reflect deeply, a student must analyze the effect the experience has had on themselves, fellow classmates, community partners, and society as a whole. ${ }^{3-8}$ Formal written reflection assignments, using specific prompts, can invite students to venture into deep reflection..$^{7-9}$ When prompts are 
properly structured, they can strongly influence the quality and authenticity of reflections generated by the student. $4,7,8$

Grading rubrics with specific criteria provide students with guidance in written reflection. Rubrics should be presented to students in advance of writing, along with descriptions of higher quality responses and less-than-satisfactory responses and points associated with each graduated response. ${ }^{29,30,31}$ Each criterion can include prompts to stimulate contemplation about various values associated with course objectives. To streamline grading, a copy of the rubric with scores and comments can be attached to students' reflections upon return.

It is essential for students to reflect on their service activity before, during, and after the experience. That way they can incorporate what they are learning into their thoughts about the project and create meaning for themselves before the experience ends. ${ }^{4,5}$ Multiple reflection papers give students the opportunity to practice writing in a new way and receive feedback from the instructor as they progress. A first reflection in which students are asked about their expectations is a good way to introduce students to the practice of written reflection. One or more reflections on how course content relates to the service project should occur during the work. A final written reflection allow students to consider the implications of their service-learning project.

\section{Values of Civic Engagement}

Civic-engagement values include civic identity, collaboration, and effective communication. According to Boyte, ${ }^{23}$ a service-learning student must feel like a part of the community, a "citizen professional," not a detached expert imparting knowledge to a disadvantaged population. Students, as scientists, are not acting on their partners but participating with their partner(s) in solving an important problem. To identify with their partner(s), students must think about what specialized knowledge they bring to the project and their limitations. They must feel a responsibility to their community as scientists.

This paper presents evidence that integration of best practices in service-learning increased expression of civic engagement values based on final written reflections of students enrolled in a service-learning-intensive environmental chemistry course from 2012 to 2017. 


\section{MEASURING THE EFFECTS OF EVOLVING PEDAGOGY}

\section{Context}

Service-Learning-Intensive environmental chemistry was taught each fall semester as a 3 credit-hour course (1 hour lecture/two hours laboratory) at an open enrollment, mid-sized, urban, Midwestern research university. The project consisted of a water-quality-monitoring project in and around a nature preserve. The fledgling course was described in 2011,24 but has evolved significantly since with integration of best practices in service learning. Academic objectives were for students to gain experience in environmental analysis and develop a greater understanding of the chemical nature of air, water, and soil.

For their service, student teams of three or four monitored twelve different sites (including a municipal well and effluents from an aluminum foundry and a wastewater treatment plant with EPA Permits to Discharge) divided amongst the teams. Monitoring parameters included anions (fluoride, chloride, nitrite, bromide, nitrate, phosphate, and sulfide), E. coli, dissolved oxygen, ammonium/ammonia, $\mathrm{pH}$, specific conductance, and heavy metals. Each team sampled water three times each semester, except from 2014 to 2016 when they sampled their sites twice but also sampled two private wells for landowners near the nature preserve. In 2017, students analyzed the private well in the nature preserve and the municipal well only and performed sediment analysis for heavy metals in the nature preserve instead of additional well analysis for private landowners. Well water quality results were presented to landowners in a report describing the parameters measured and their significance including recommended actions to be taken if a contaminant was discovered. Well owners also received a special invitation to the public presentation on water quality in the nature preserve, which served as the students' final exam. Private well locations were not made public. Several wells contained nitrate and arsenic in excess of the EPA Drinking Water limit. ${ }^{25}$ The foundry discharged wastewater to sinkhole (a violation of its permit) therefore students were not able to sample the effluent but documented and reported the violation to the community and EPA. Results of the monitoring project will be published elsewhere.

Increased civic engagement by students was a critical goal for the course. Various best-practice pedagogies were incorporated over time. In 2011 , the only reflection activity was a private 
presentation to the manager of the nature preserve. A survey was introduced in 2012 (Box 1) with a few questions related to civic engagement. Not all students turned in the final reflection since it was not graded.

In 2013, students were presented with information on Boyte's concept of the "Citizen Scientist,"23 From 2015 on, students were assigned to read and discuss two articles from $C \& E$ News, "Volunteers Against Pollution" 26 and "Citizen Science Faces Pushback." ${ }^{27}$ Collaborative work guidance and group dynamics were added to the curriculum in 2014. Referring to student groups as "teams" seemed increase cohesion between the students.

Reflection was formalized in 2013 by assigning multiple formal written reflection papers, groundwater analysis reports for private partners (2014-2017), and a public presentation of results (verbal reflection) with implications and recommendations for the community. A written reflection grading rubric (Table 1) was adapted from other published rubrics 28,29 and based on the American Association of Colleges \& Universities (AAC\&U) Value Rubrics ${ }^{30}$ for Civic Engagement. Students were provided with the rubric at the start of the term. General prompts were included with each grading criteria shown in Table 1.

\section{Box 1. 2012 Student Final Feedback Form}

How much time did you spend per week on this course, estimate the percent of time you spent in the lab and outside the lab (I know it varied a lot, just guestimate an average).

What percentage of time did you spend working in groups as opposed to alone? How did you feel about working in groups and being graded as a group?

What did you think we should have spent more time on? Comment on class time, homework, lab time, and course content.

What do you think we should have spent less time on? Comment on class time, homework, lab time, and course content.

What was the most satisfying part of the course for you personally?

What was the most frustrating part of the course for you personally?

How do you feel about making a contribution to society as part of this course?

Do you think the unconventional style of the course increased or decreased your learning about environmental chemistry as compared to a lecture-style course with formal labs that have pre-determined results?

How do you feel about the "products" we produced such as the poster, the PowerPoint presentation, and the SOP manual?

What would you recommend for the future direction of the course? 
For their first written reflection, students were asked about past experiences and expectations for the course. During data collection and analysis, students were asked to write about how they were learning course content as they performed their service activities. In the final reflection, students reflected on their overall experience including the public presentation. From 2013 to 2015, students were given additional final reflection prompts (Box 2) specific to civic engagement. In an effort to streamline instructions, the use of specific prompts was stopped in 2016 and 2017 but use of the rubric was continued. Students were told to write at least 800 words, but no maximum limit was set. 


\begin{tabular}{|c|c|c|c|c|c|}
\hline CRITERIA & $\begin{array}{c}4^{b} \\
\text { EXCELLENT }\end{array}$ & VERY GOOD & $\begin{array}{c}2 \\
\text { SATISFACTORY }\end{array}$ & NEEDS WORK & $\stackrel{0}{\text { UNSATISFACTORY }}$ \\
\hline $\begin{array}{l}\text { Writing Quality } \\
\text { Do you convey your } \\
\text { ideas intelligently } \\
\text { and correctly? }\end{array}$ & $\begin{array}{l}\text { Writing style } \\
\text { clearly expresses } \\
\text { meaning and } \\
\text { viewpoints. } \\
\text { Excellent } \\
\text { grammar and } \\
\text { syntax. No } \\
\text { spelling errors. }\end{array}$ & $\begin{array}{l}\text { Writing style } \\
\text { clearly expresses } \\
\text { meaning and } \\
\text { viewpoints. } \\
\text { Proper use of } \\
\text { grammar and } \\
\text { syntax. No } \\
\text { spelling errors. }\end{array}$ & $\begin{array}{l}\text { Writing style is } \\
\text { clear and conveys } \\
\text { meaning. A few } \\
\text { grammar and } \\
\text { syntax errors. No } \\
\text { or few spelling } \\
\text { errors. }\end{array}$ & $\begin{array}{l}\text { Writing style } \\
\text { mostly clear. } \\
\text { Grammar and } \\
\text { syntax need } \\
\text { attention. } \\
\text { Spelling errors. }\end{array}$ & $\begin{array}{l}\text { Writing style is } \\
\text { poor. Ideas are } \\
\text { not clearly } \\
\text { articulated. } \\
\text { Improper use of } \\
\text { grammar and } \\
\text { syntax. Spelling } \\
\text { errors. }\end{array}$ \\
\hline $\begin{array}{l}\text { Description of } \\
\text { Service-Learning } \\
\text { Activity } \\
\text { What } \\
\text { measurements } \\
\text { were taken and } \\
\text { how was this } \\
\text { accomplished? } \\
\text { What was your role } \\
\text { in the activity? }\end{array}$ & $\begin{array}{l}\text { Complete } \\
\text { description of } \\
\text { activities. } \\
\text { Demonstrated } \\
\text { clear knowledge } \\
\text { of techniques } \\
\text { used. Able to } \\
\text { critically evaluate } \\
\text { data and results. } \\
\text { Played a } \\
\text { significant role in } \\
\text { the project. }\end{array}$ & $\begin{array}{l}\text { Complete } \\
\text { description of the } \\
\text { S-L activities. } \\
\text { Demonstrates } \\
\text { adequate } \\
\text { knowledge of } \\
\text { techniques used } \\
\text { and insight into } \\
\text { the imitations of } \\
\text { techniques and } \\
\text { interpretation of } \\
\text { data. Participated } \\
\text { fully. }\end{array}$ & $\begin{array}{l}\text { Adequate } \\
\text { description of S-L } \\
\text { activity and } \\
\text { personal role in } \\
\text { collecting and } \\
\text { evaluating data } \\
\text { and presenting } \\
\text { results. } \\
\text { Demonstrates } \\
\text { adequate } \\
\text { knowledge of } \\
\text { techniques used. }\end{array}$ & $\begin{array}{l}\text { S-L activity } \\
\text { reported as a } \\
\text { sequence of } \\
\text { events. } \\
\text { Description of } \\
\text { personal role in } \\
\text { collecting and } \\
\text { evaluating data } \\
\text { and presenting } \\
\text { results. Limited } \\
\text { knowledge of } \\
\text { methods used. }\end{array}$ & $\begin{array}{l}\text { Inadequate } \\
\text { description of } \\
\text { activity and } \\
\text { personal role in } \\
\text { collecting and } \\
\text { evaluating data } \\
\text { and presenting } \\
\text { results. Lack of } \\
\text { understanding of } \\
\text { methods used. }\end{array}$ \\
\hline $\begin{array}{l}\text { Insights and } \\
\text { Understanding } \\
\text { Were course } \\
\text { learning objectives } \\
\text { met for you? Why } \\
\text { or why not? } \\
\text { What did you learn } \\
\text { in the course that } \\
\text { related to your S-L } \\
\text { activity? } \\
\text { What did you learn } \\
\text { from performing the } \\
\text { S-L activity? }\end{array}$ & $\begin{array}{l}\text { Explains how } \\
\text { course content is } \\
\text { integrated into the } \\
\text { project. } \\
\text { Demonstrates } \\
\text { awareness of } \\
\text { complexity of the } \\
\text { issues with proper } \\
\text { reasoning. } \\
\text { Evaluates } \\
\text { personal learning } \\
\text { style. }\end{array}$ & $\begin{array}{l}\text { Some insights into } \\
\text { significance of } \\
\text { project. Explains } \\
\text { how course } \\
\text { content is related. } \\
\text { Some sense of } \\
\text { complexity of the } \\
\text { issues with proper } \\
\text { reasoning. } \\
\text { Evaluates } \\
\text { personal learning } \\
\text { style. }\end{array}$ & $\begin{array}{l}\text { Explains } \\
\text { significance of } \\
\text { results and how } \\
\text { they are related to } \\
\text { course content. } \\
\text { Some sense of } \\
\text { complexity but } \\
\text { most insights are } \\
\text { simplistic. } \\
\text { Some discussion } \\
\text { about personal } \\
\text { learning style. }\end{array}$ & $\begin{array}{l}\text { Report of work } \\
\text { done with limited } \\
\text { insight about how } \\
\text { fieldwork is } \\
\text { related to } \\
\text { learning of } \\
\text { course content. } \\
\text { Lack of thought } \\
\text { about personal } \\
\text { learning style. }\end{array}$ & $\begin{array}{l}\text { No evidence of } \\
\text { understanding } \\
\text { how course } \\
\text { content relates to } \\
\text { work. No } \\
\text { evaluation or } \\
\text { interpretation of } \\
\text { results. } \\
\text { Lack of thought } \\
\text { about personal } \\
\text { learning style. }\end{array}$ \\
\hline $\begin{array}{l}\text { Commitment to } \\
\text { the Project and } \\
\text { the Team } \\
\text { Has your } \\
\text { experience affected } \\
\text { your thinking about } \\
\text { the issues and } \\
\text { possible solutions? } \\
\text { Did you overcome } \\
\text { any problems? }\end{array}$ & $\begin{array}{l}\text { Demonstrates } \\
\text { commitment to the } \\
\text { activity and team. } \\
\text { Finds solutions to } \\
\text { problems. } \\
\text { Generates ideas } \\
\text { for future work. }\end{array}$ & $\begin{array}{l}\text { Description of } \\
\text { personal } \\
\text { participation in the } \\
\text { activities of the } \\
\text { project. } \\
\text { Demonstration of } \\
\text { a commitment to } \\
\text { the activity and } \\
\text { finding solutions to } \\
\text { problems. }\end{array}$ & $\begin{array}{l}\text { Description of } \\
\text { personal } \\
\text { participation in the } \\
\text { activities of the } \\
\text { project. Reliance } \\
\text { on others to } \\
\text { resolve problems } \\
\text { or interpret } \\
\text { results. }\end{array}$ & $\begin{array}{l}\text { Description of } \\
\text { personal } \\
\text { participation in } \\
\text { the activities of } \\
\text { the project. } \\
\text { Reliance on } \\
\text { others to resolve } \\
\text { problems or } \\
\text { interpret results. }\end{array}$ & $\begin{array}{l}\text { No evidence of a } \\
\text { commitment to the } \\
\text { project. Lack of } \\
\text { participation in the } \\
\text { team's work or } \\
\text { class discussion. }\end{array}$ \\
\hline $\begin{array}{l}\text { Personal } \\
\text { Achievement \& } \\
\text { Development } \\
\text { Did any of the } \\
\text { activities give you a } \\
\text { sense of personal } \\
\text { achievement as a } \\
\text { Citizen Scientist? } \\
\text { Have your goals or } \\
\text { views changed? }\end{array}$ & $\begin{array}{l}\text { Evaluates the } \\
\text { implications of } \\
\text { results for self, S- } \\
\text { L partner, and } \\
\text { public. Evidence } \\
\text { of impact on } \\
\text { career goals or } \\
\text { feelings of } \\
\text { personal } \\
\text { accomplishment. }\end{array}$ & $\begin{array}{l}\text { Expresses } \\
\text { satisfaction with } \\
\text { activities and } \\
\text { results. Aware of } \\
\text { impact on career } \\
\text { goals or feelings } \\
\text { of personal } \\
\text { achievement. }\end{array}$ & $\begin{array}{l}\text { Explanation of a } \\
\text { personal increase } \\
\text { in sensitivity of the } \\
\text { issues, or a } \\
\text { change of } \\
\text { attitude, and } \\
\text { awareness. }\end{array}$ & $\begin{array}{l}\text { Participant } \\
\text { reports efforts but } \\
\text { is unaffected by } \\
\text { the project and } \\
\text { the outcomes. }\end{array}$ & $\begin{array}{l}\text { Negative attitude } \\
\text { reported about } \\
\text { work on project. } \\
\text { Excessive } \\
\text { boredom and } \\
\text { frustration with } \\
\text { little effort to find } \\
\text { resolution. }\end{array}$ \\
\hline
\end{tabular}


Other written forms of reflection were included that required teams to collaborate on reports and documents. In 2012 and 2013, each team prepared a standard operating procedure (SOPs) based on EPA methods for their analysis and sampling procedures. Successive classes edited the originals or added additional SOPs, as needed. From 2014-2016, each team prepared two or more well analysis reports for their private partners. In 2017 , each team wrote a report on heavy metals in sediments in the nature preserve. Individual written reflections accounted for $15 \%$ of the grade (100 points), the presentation was $15 \%$, team SOPS, well reports, or sediment reports were another $12-15 \%$, and laboratory notebooks (7-8\%) were counted as service work. Homework assignments (18\%) and two 100-point exams (30\%) rounded out the curriculum. In 2013, no exams were given to assess content learning but many students expressed concern about not having exam scores as proof that they had learned something. Some were also upset that a large percentage of their grade depended on the success of their team. To reduce student discomfort with group grading, homework and exams were restored to the curriculum in 2014.

Box 2. Final Reflection Prompts
What did you learn in your course that relates to your understanding of [the nature
preserve] and the environment?
What problem(s) did you help solve that enhanced your role as a citizen scientist? How
did you accomplish this?
How has your experience in this course affected your role in the community?
What personal, academic, or career goals did you achieve in this course? Has your
experience in this course affected your thinking about your personal, academic, or
career goals?
As a result of taking this course, will you be more willing in the future to use your
scientific skills to help solve problems in your community?

Students were predominately Chemistry majors but Earth and Environmental Sciences and Biology students also participated. Prerequisites were organic chemistry and quantitative analysis. Only a few students had previously participated in service learning, and none had taken a sciencerelated service course. Table 2 gives course demographics. Students were fairly evenly distributed between male and female with $78 \%$ undergraduates and $22 \%$ graduate students including $9 \%$ international students. 


\begin{tabular}{|l|c|c|c|c|c|}
\hline \multicolumn{7}{|l|}{ Table 2. Course Demographics } \\
\hline Year & Female & Male & Juniors/Seniors & Graduate & International \\
\hline $2012^{a}$ & 8 & 7 & 7 & 8 & 0 \\
\hline 2013 & 5 & 7 & 9 & 3 & 2 \\
\hline 2014 & 3 & 6 & 8 & 1 & 1 \\
\hline 2015 & 6 & 2 & 6 & 2 & 2 \\
\hline 2016 & 6 & 5 & 11 & 0 & 0 \\
\hline 2017 & 2 & 7 & 9 & 0 & 1 \\
\hline TOTAL & 30 & 34 & 50 & 14 & 6 \\
\hline
\end{tabular}

${ }^{a}$ The course was taught twice in 2012 with the same curriculum so the 2012 results were bundled.

\section{MEASURING THE EFFECTS OF EVOLVING PEDAGOGY}

\section{Data Collection and Analysis}

All available 2012 "feedback forms" and 2013-2017 final reflection papers were collected and deidentified. Feedback responses from 2012 are final reflections that included questions intended to promote reflection. The 2012 cohort served as a control before best practices in service learning were implemented. A list of relevant civic-engagement values was developed by the co-authors in 2018 and was used to retroactively evaluate student final reflections (Box 3) to specifically assess whether expression of civic engagement values had changed as the pedagogy evolved. Authors flagged the presence or absence of authentic statements about civic-engagement values but did not code vague statements describing the project as "fun" or the nature preserve as "beautiful," for example, unless the student went on to explain the statement in terms of civic engagement, content mastery, teamwork, or communication. Multiple expressions of a single value only counted once since that value had been expressed. Statements indicating civic disengagement were not coded; for example complaints about being graded as a team. The authors coded final reflections from each class independently then met to discuss their results and reached complete consensus for all reflections from across all of the six cohorts that were analyzed. Grades on reflections were not evaluated because prompts were varied and students' writing changed focus. Therefore, the grades did not directly reflect their level of civic engagement, especially in 2016 and 2017. Length of final reflections ranged from half a page to several pages.

Expressions the five the civic-engagement values were correlated using Pearson's $r$ for each of the individual student reflections to identify relationships among them. An online Mann-Whitney rankedsum test ${ }^{31}$ was applied to obtain $\mathrm{p}$-values for unpaired, non-parametric data and checked against 
Mann-Whitney significance tables ${ }^{32}$ using ranked sums calculated in Excel (see Supporting Information).

Box 3. Civic Engagement Values Assessed in Students' Final Reflections

Civic Identity

Value 1 (V1): Student explored the idea of "Who am I in my community?"

Value 2 (V2): Student expressed continued commitment to civic engagement.

Personal Development

Value 3 (V3): Student connected academic knowledge with civic engagement.

Communication Skills

Value 4 (V4): Student discussed collaborative work roles such as leadership and team dynamics.

Value 5 (V5): Students reflected on tailoring the presentation and/or report to the audience.

Figure 1 (following page) presents the effects of modifying pedagogy on expression of civic-

engagement values. Best-practice pedagogies are listed for each year of assessment along with the percentage of students expressing each of the five values from Box 3.

\section{Value 1: Who am I in my community?}

In 2012 (before best practices), there were no expressions (0\%) of civic identity despite being asked how they felt about contributing to society. In 2013, $91 \%$ of students expressed Value 1 after the incorporation of written reflection and the public presentation. The Proportion of students who made authentic statements expressing Value 1 peaked at 100\% (2014-2015) when students were provided with the grading rubric, specific prompts (Box 2), and increased interaction with partners (private well analysis). Value 1 expression decreased to $73 \%$ in 2016 for students who only had the rubric for their written reflections. In 2017, the expression of Value 1 decreased further to $45 \%$ when students did not perform well analysis with private partners.

Several students expressed how they enjoyed being a scientist with something important to say. One student wrote, "I could tell that the people were genuinely concerned about the information we were giving them, and this meant a lot to me as the scientist." Another student wrote, "As evidenced by the actions taken by the community, it did impact our partners and helped improve their water quality. I'm glad the class was able to do something positive, and that I was a part of it." Yet another said, "It was the first time as a student that someone has actually responded to something I had directly worked on." Several students used the expression "citizen scientist" when referring to themselves. 


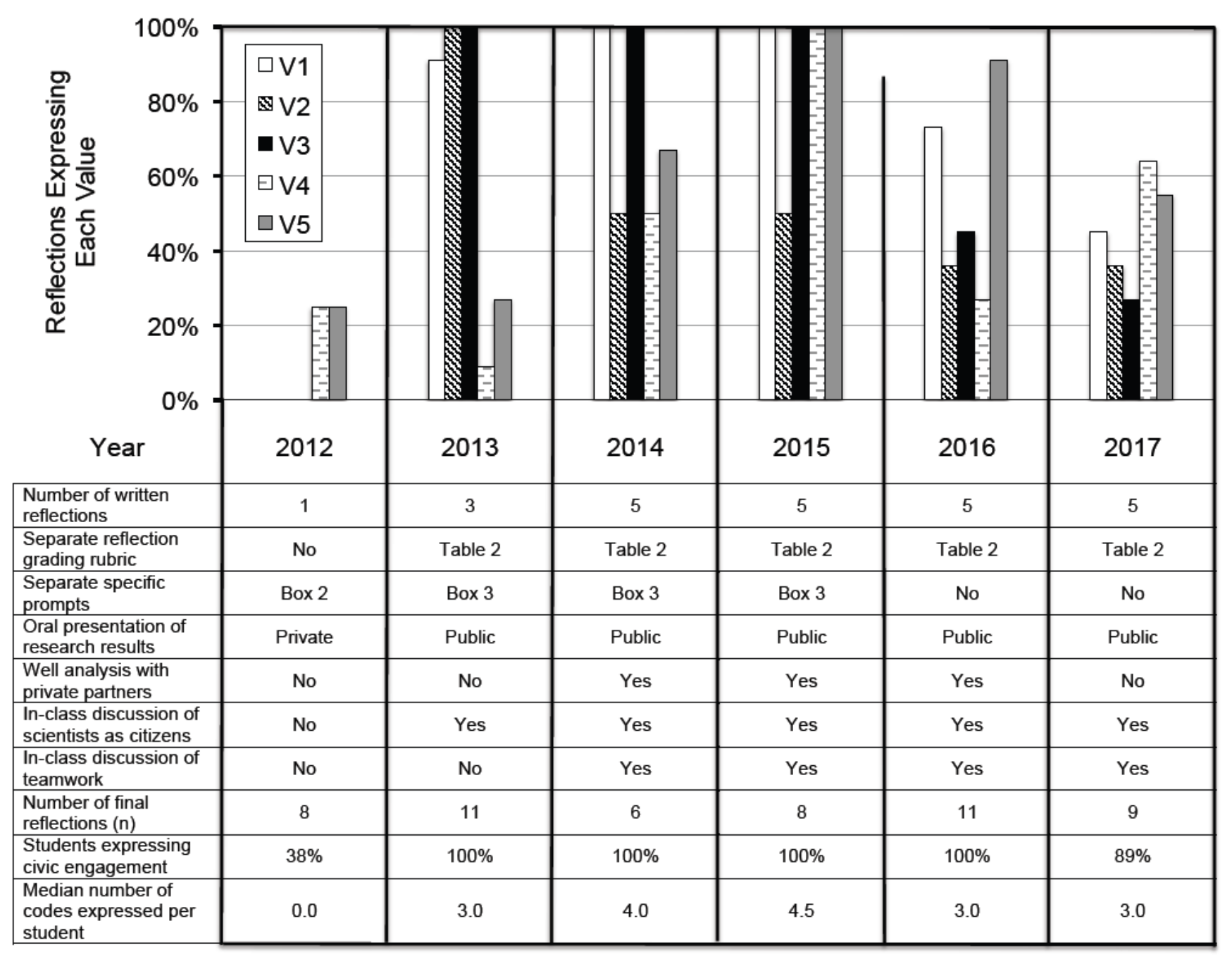

Figure 1. The effect of modified pedagogy on expression of civic-engagement values in a service-learningintensive environmental chemistry course. Best-practice pedagogies are listed for each year of assessment along with the median number of codes (V1-V5) expressed per student (Box 3).

When students identified beneficiaries of their work, it was occasionally an abstract entity, such as the nature preserve, but were more often specific people whom they had met, such as people whose well water they tested, people they spoke to at the nature preserve, or members of the audience at the presentation.

\section{Value 2: Continued commitment to civic engagement}

The 2012 cohort expressed no continued commitment to civic engagement. In later years, expression of Value 2 varied, from $36-100 \%$, (Figure 1). About half of the students responded to prompts that 
explicitly addressed their futures. Some described their future selves more broadly as problemsolvers, educators, or people who communicated scientific findings to the public as agents of change. A few students used the word "community" when writing about the future for example, "I am now more compelled to search for endeavors that seek to improve the community and cause it to thrive."

\section{Value 3: Connecting academic knowledge with civic engagement}

The 2012 cohort made no statements connecting learning with helping their community, although some stated that learning new analytical methods would increase their chances at gainful employment. Every student in the 2013-2015 classes, who gave a public presentation and wrote multiple reflection papers with the rubric and specific prompts, expressed Value 3 (Figure 1).

Some reflection statements connected scientific data to expressions of alarm such as "There are people who allow their children to play around in this water, and knowing that the arsenic content is so high, I would not advise that anymore." One student wrote about how the director of the nature preserve took action based on well water analysis results at a house with residents and where private functions, such as weddings, are held, "The well site there had an unsafe level of nitrate in the water . . . swift action was taken, and a reverse osmosis filtration system was installed . . Because of our analysis, the water quality for a household was greatly improved." "I believe they will follow the class' suggestions of not playing in the water after a rain event or downstream of the WWTP," expressed one relieved student.

Students who had specific prompts in addition to the rubric universally expressed Value 3 (20132015). Expression of Value 3 fell to $45 \%$ in 2016 when students had only the rubric. In 2017, students had no specific prompts and did not do well analysis for private partners. Their expression of Value 3 fell to $27 \%$. Without emphasis on civic engagement, students wrote about other aspects of the course such as the challenges of the project, which were many.

\section{Value 4: Teamwork}

The investigators flagged descriptions of roles and dynamics within teams, the class, or, in one case, within the community. Positive, detailed discussions of teamwork (V4) were generally more common in reflections after discussion of collaborative learning occurred in class, but expressions of V4 varied widely (Figure 1). In 2012, 25\% of students commented on collaboration such as in the following statement, " ...everyone pretty much carried their weight and it gave us a chance to work with others 
and still be productive...", although most comments were negative and not coded, such as "Grades should not be given as a group" and "...some members of the lab were lazier than others."

Later, students wrote about virtues and skills that made teamwork successful, such as a "work ethic", increasing skill in spoken English, and a reference to classmates as "talented people". One student stated that their team had "communicated very well, collaborated effectively, and resolved disagreements by studying our data or SOP, thinking critically, and coming to a consensus about whose argument was the most sound and logical."

The variability in V4 responses likely results from the fact that team dynamics are personality driven. Not all students will serve as leaders, but leaderless teams struggled and some failed to contribute their part of the data and results to the rest of the class members in a timely manner. Team assignments must often be made based on class schedules, but every team must have at least one member who is willing to lead. It is critical that students learn how to communicate effectively with team members and to cooperate.

\section{Value 5: Tailoring the presentation to the audience: verbal and written}

Tailoring the presentation to the audience (2014-2017) included remarks about selecting the most important data, substances that posed the greatest danger, and concerns about how to present the data "intuitively" and "accurately." Since the public presentation included a questions-and-answer session, students had an opportunity to assess the audience's understanding and respond to questions with answers that were basically re-tailored information. Example comments included: "Scientists can come off as very scary and hard to understand but by doing research in the community you make connections with the people," "They wanted to know a lot more about the wells, and how to fix the nitrate problems," and "I didn't expect so many questions, or for so many people to attend. I was astonished by the thoughtful quality of the questions, which showed that not only were people paying close attention to the presentation, but that many people in the audience were well educated on the subjects we covered." Students valued the connection they had with their partners and their public audience; 55 - $100 \%$ of students made positive statements relating to V5 from 2014-2017.

\section{Correlation Patterns}

Patterns of correlation among expressions of civic engagement indicate three constructs (Supporting Information). Students who expressed one of the first three values of civic engagement were more 
likely to express at least one of the other three (V1-V3) than students who did not $(37 \%<\mathrm{r}<$ $68 \%$ ). The first three values describe a general, abstract civic identity. Students who have begun to develop such an identity will express connections between themselves and the community partners with their water quality research (V1), between their future selves and the community (V2), and between their current observations and partners (V3). The last two, V4 and V5, address specific experiences within the course: the challenges of teamwork and of public presentation. Written expressions of V4 and V5 were not correlated with one another nor with any of the first three values ($20 \%<r<24 \%)$.

The Mann-Whitney Test examines differences in distributions. The likelihood that the difference in distribution of codes per reflection before and after best practices is due to chance is extremely small (Figure 2(a), $\mathrm{p} \cong 0.00002)$. A comparison of the number of codes for the 2013-2015 conditions where students were provided with a grading rubric and specific prompts to aid in their written reflections and the number of codes for the 2016-2017 conditions, where students were only provided with the grading rubric but not specific prompts, also shows that the likelihood that the differences are due to chance is extremely small (Figure $2 b, p \cong 0.0028$ ). 

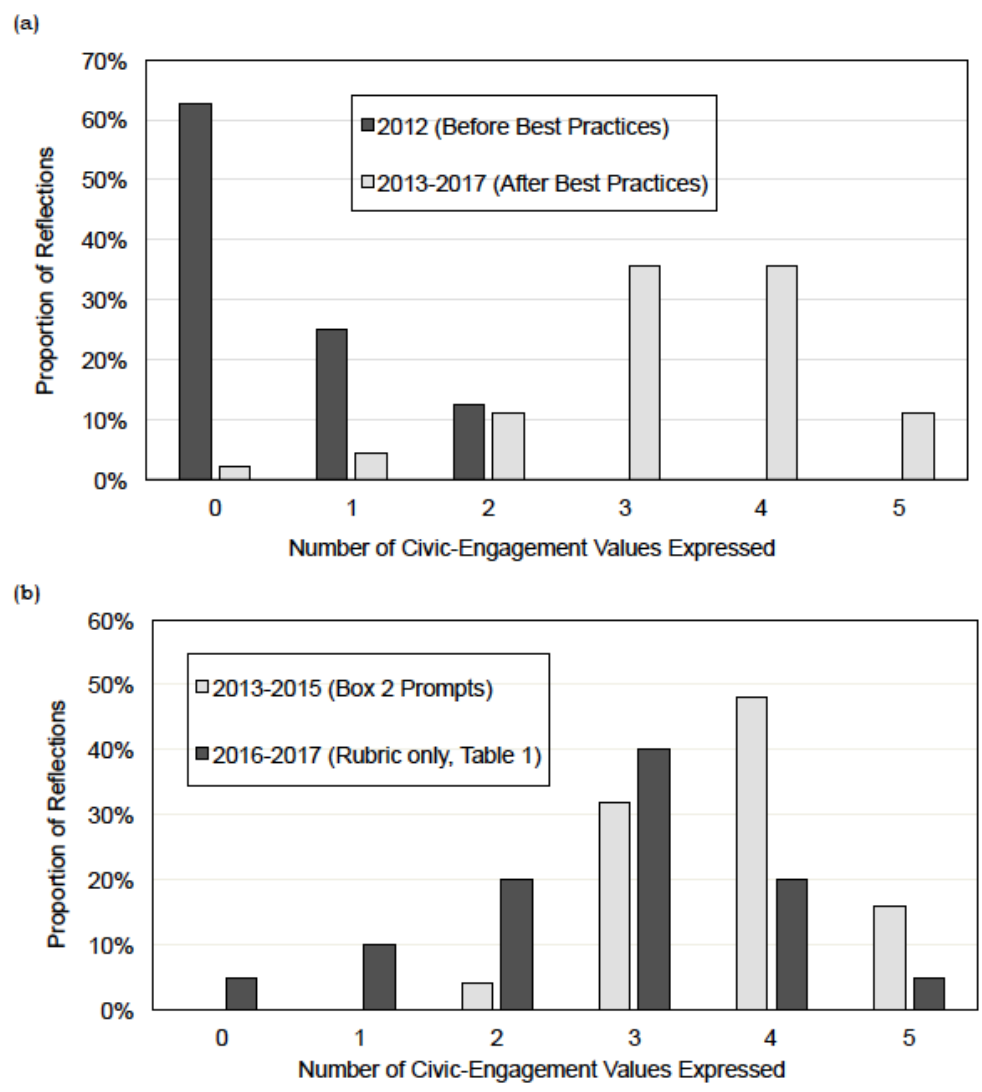

Figure 2. The distribution of civic-engagement expression in formal written reflections (a) before (2012) and after (2013-2017) when best practices were applied and (b) with best practices using a grading rubric and specific prompts related to civic engagement (2013-2015) and with the rubric only (2016-2017).

\section{LIMITATIONS}

The authors' idea of desirable civic-engagement values evolved over the course of the six years that reflection papers were collected but the civic-engagement values were not specifically defined until after the sixth year. Therefore, the list of five values was applied retroactively in order to evaluate the effectiveness of changes in pedagogy.

The instructor observed that students who struggled with course content were the least likely to express civic-engagement values. The authors decided not to evaluate grades because assessment policies changed as the course evolved. Course grades alone do not indicate civic engagement.

Sample size was still relatively small because class size is limited to 12 students. Additionally, most but not all students turned in the final reflection. This study looked at only final written reflections from 2012 to 2017 since it was more focused on civic engagement. 
Hence, it was beyond the scope of this paper to evaluate civic engagement development over the course of the term. This study only evaluated written statements of civic values by students and did not take into account verbal statements expressed in class or with partners.

\section{IMPLICATIONS}

Reflection is important at the beginning, middle, and end of service learning. When carefully crafted prompts were used in addition to the rubric, the rate of authentic statements by students on civic-engagement values increased dramatically. The results show that repeated guided reflection increased expression of civic-engagement values. Students who were given detailed prompts in addition to a grading rubric were more likely to express civic identity authentically in their reflections. Students who only had the rubric exhibited civic-engagement values at a lower rate because they also wrote about other aspects of the service-learning experience such as explaining the results but not about connecting with the community. Students who did not participate in regular reflection expressed no civic-engagement values, except in vague statements, or they expressed civic disengagement. The initial beliefs of some students about the community's disinterest in science were dramatically altered by their positive interactions with their community partners.

Students who wrote five reflections (2014-2016) had higher rates of expression of teamwork values and communication with partners than students who only wrote three (2013), but the rates of expression of those values varied widely within later sections. Teamwork roles seem to be personalitydriven so training on collaborative work should focus on how to cooperate.

Box 4 is a list of the best-practice pedagogies that were most effective based on the results of this study. 
Box 4. Best-practice pedagogies to achieve enhanced civic engagement:

1. Teamwork and group dynamics were addressed in the classroom at the beginning.

2. The concept of the scientist as a citizen was addressed in the classroom at the beginning.

3. Students produced three or more formal written reflection papers including a final reflection that was more focused on civic engagement values.

4. Reflection prompts were specific to each reflection paper and a grading rubric was provided.

5. The project included individual citizens as partners who received a personalized report from the team.

6. The community and partners were informed of the results in a formal oral presentation.

Our results support what is already known about best practices in service-learning and how they increase civic engagement. ${ }^{12}$ The integration of best practices increased expression of civic-engagement values significantly. When compared to the 2012 control cohort, most students in the 2013-2017 sections were able to authentically express a civic identity, discuss how their service project had contributed to learning course content, and gained experience as collaborators and communicators with their peers and partners. Students in the 2012 cohort did not express engagement with the community even though they participated in service learning, perhaps because they had little opportunity to communicate more profound thoughts regarding the significance of their project. The greatest effect of changing pedagogy occurred when regular reflection was done using specific prompts and students interacted with their partners by sampling their wells and providing them with a report.

\section{SUPPORTING INFORMATION}

The Supporting Information is available on the ACS Publications website at DOI:

10.1021/acs.jchemed.9b00221.

- Examples of written reflections (pdf)

- Results and statistical analyses (Excel)

\section{AUTHOR INFORMATION}

\section{Corresponding Author}

*E-mail: audrey.mcgowin@wright.edu

\section{ORCID}

Audrey E. McGowin: 0000-0003-0388-8829

Rebecca Teed: 0000-0002-8570-6015

\section{Notes}

The authors declare no competing financial interest. 


\section{ACKNOWLEDGMENTS}

The authors express gratitude to students who participated in the service-learning course, the Wright State Department of Chemistry, Cathy Sayer for service-learning guidance, and Dorothy Bair for manuscript review.

\section{REFERENCES}

1. Boyte, H., Hollander, E. Wingspread Declaration on Renewing the Civic Mission of the American Research University, 1999, Providence RI: Campus Compact. https://digitalcommons.unomaha.edu/slceciviceng/8/ (accessed Feb 2019).

2. Mitchell, T. D.; Soria, K. M. Seeking Social Justice: Undergraduates' Engagement in Social Change and Social Justice at American Research Universities. Chapter 13 in Civic Engagement and Community Service at Research Universities: Engaging Undergraduates for Social Justice, Social Change and Responsible Citizenship; Soria, K. M.; Mitchell, T. D. (eds.); Palgrave Macmillan UK: London, 2016; pp. 248-249.

3. Butin, D. Service-Learning in Theory and Practice: The Future of Community Engagement in Higher Education; Palgrave Macmillan: New York, 2010; pp 1-45.

4. Jacoby, B. Service-Learning Essentials: Questions, Answers, and Lessons Learned; Jossey-Bass: San Francisco, 2015; pp 1-50.

5. Bringle, R. G.; Hatcher, J. A. Reflection in Service Learning: Making Meaning of Experience. Educational Horizons, 1999, 179-185.

6. Harkavy, I; Hartley, M. Pursuing Franklin's Dream: Philosophical and Historical Roots of ServiceLearning. Am. J. Community. Psychol. 2010, 46, 418-427.

7. Ash, S. L.; Clayton, P. H. The Articulated Learning: An Approach to Guided Reflection and Assessment. Innovative Higher Educ. 2004, 29(2), 137-154.

8. Molee, L. M.; Henry, M. E.; Sessa, V. S.; McKinney-Prupis, E. R. Assessing Learning in ServiceLearning Courses Through Critical Reflection. J. Experiential Educ. 2010, 33(3), 239-257.

9. Bloomquist, C. Reflecting on Reflection as a Critical Component in Service Learning. J. Education for Library and Information Science, 2015, 56 (2), 169-172.

10. Barnes, M. E.; Caprino, K. Analyzing Service-Learning Reflections Through Fink's Taxonomy. Teaching in Higher Education, 2016, 21 (5), 557-575.

11. Wium, A.; du Plessis, S. The Usefulness of a Tool to Assess Reflection in a Service-Learning Experience. African Journal of Health Professions Education, 2016, 8 (2), 178-183.

12. Mabry, J. B. Pedagogical variations in service-learning and students outcomes: how time, contact, and reflection matter, Michigan Journal of Community Service Learning, 1998, Fall, 3247.

13. American Chemical Society Committee on Professional Training Newsletter, 13(1), Spring 2016.

14. Dewey, J. How We Think: A Restatement of the Relation of Reflective Thinking to the Educative Process; D. C. Heath and Company: Boston, 1933; pp. 1-301. 
15. Krathwol, D. R. A Revision of Bloom's Taxonomy: An Overview. Theory Into Practice, 2001, 41(4), 212-218.

16. Fink, L. D. Creating Significant Learning Experiences: An integrated approach to designing college courses, Jossey-Bass, 2003.

17. Smit, E. M.; Tremethick, M. J. Value of Online Group Reflection After International ServiceLearning Experiences. Nurse Educator, 2017, 42(6), 286-289.

18. Donaghy, K. J.; Saxton, K. J. Service Learning Track in General Chemistry: Giving Students a Choice. J. Chem, Educ. 2012, 89, 1378-1383.

19. Sewry, J. D.; Glover, S. R,; Harrison, T. G.; Shallcross, D. E.; Ngcoza, K. M. Offering Community Engagement Activities To Increase Chemistry Knowledge and Confidence for Teachers and Students. J. Chem. Educ. 2014, 91, 1611-1617.

20. Tomasik, J. H.; LeCaptain, D.; Murphy, S.; Martin, M.; Knight, R. M.; Harkle, M. A.; Burke, R.; Beck, K.; Acevedo-Polakovich, I. D. Island Explorations: Discovering Effects of Environmental Research-Based Activities on Analytical Chemistry Students. J. Chem. Educ. 2014, 91, 18871894.

21. Latch, D. E. Instrumental Analysis at Seattle University: Incorporating Environmental Chemistry and Service Learning into an Upper-Division Laboratory Course; ACS Symposium Series; American Chemical Society: Washington, DC, 2014; pp 193-208.

22. Glover, S. R.; Sewry, J. D.; Bromley, C. L.; Davies-Coleman, M. T.; Hlengwa, A. The Implementation of a Service-Learning Component in an Organic Chemistry Laboratory Course. $J$. Chem. Educ. 2013, 90, 578-583.

23. Boyte, H. C. The Citizen Solution: How you can make a difference; Minnesota Historical Society Press, 2008, pp. 143-157.

24. Kammler, D. C.; Truong, T. M.; VanNess, G.; McGowin, A. E. A Service-Learning Project in Chemistry: Environmental Monitoring of a Nature Preserve. J. Chem Educ. 2012, 89, 1384-1389.

25. United States Environmental Protection Agency National Primary Drinking Water Regulations. https://www.epa.gov/ground-water-and-drinking-water/national-primary-drinking-waterregulations (accessed Feb 2019).

26. Gibb, S.K. Volunteers Against Pollution, Chemical \& Engineering News, 2015, 93(36), 12-17.

27. Gibb, S. K. Citizen Science Faces Pushback, Chemical \& Engineering News, 2015, 93(36), 18-19.

28. Burton, D. A Service Learning Rubric, VCU Teaching, Virginia Commonwealth University, March $17,1999$.

29. Acoba, F; Korey-Smith, K. Service-Learning Reflection Rubric rating sheet (spring 2011). http://ofie.kapiolani.hawaii.edu/wp-content/uploads/2013/01/slratingsheet3.pdf (accessed Feb 2019).

30. Civic Engagement Value Rubric, Association of American Colleges and Universities. https://www.aacu.org/civic-engagement-value-rubric (accessed Feb 2019). 
31. Mann Whitney Test calculator, Wilcoxon rank sum test (unpaired, two sample) calculator. http://astatsa.com/WilcoxonTest/ (accessed March 2019).

32. Zaiontz, C. Real Statistics Using Excel: Mann-Whitney Table. http://www.realstatistics.com/statistics-tables/mann-whitney-table/ (accessed March 2019). 